\title{
50TH ANNIVERSARY OF THE BRITISH INSTITUTE OF INTERNATIONAL AND COMPARATIVE LAW
}

On 17 November 2008 the British Institute of International and Comparative Law, under whose auspices the International and Comparative Law Quarterly is published, celebrates its 50th anniversary. The Institute was created by the merger of the Society of Comparative Legislation (founded in 1894) and the Grotius Society (founded in 1915 and named after the 16th century Dutch jurist Hugo Grotius, regarded as one of the founders of international law). This merger created an independent research body, unaffiliated to any university and a charity, which is committed to the understanding, development and practical application of international and comparative law.

The Memorandum and Articles of Association of the Institute, when it was incorporated on 17 November 1958, were signed by a number of the most eminent international and comparative lawyers of the 20th century. They included: Lord (Tom) Denning, Professor Geoffrey Cheshire, Lord (Kenneth) Diplock, Sir Gerard Fitzmaurice, Sir Hersch Lauterpacht, FA Mann, Lord (Arnold) McNair, Sir Kenneth Roberts-Wray, Professor Georg Schwarzenberger, Lord (Hartley) Shawcross and Lord (Richard) Wilberforce. This array of some of the finest judges, practitioners, academics and government officials, both as members of the Institute and as members of the governing board, continues to this day. Indeed, Lord Denning became the Institute's first Chairman of its Council of Management (as the Board of Trustees was then known), and then its first President. The second and current President of the Institute is Lord (Robert) Goff, who, prior to being President, was the Chairman of the Council of Management and Senior Law Lord. The current Chairman of the Institute is Lord (Tom) Bingham, who became its Chairman in November 2001, not long after he was appointed as Senior Law Lord.

The intention of the founders was that the Institute would have two main objects:

1. To promote by means of study groups, meetings and conferences the study and development of international law and comparative law (including foreign law);

2. To promote or commission research into international law and comparative law including foreign law) and to publish or arrange for the publication of the results of that research (Memorandum of Association, Article 3).

These two objects have remained at the heart of the Institute's activities for 50 years. The many lectures, seminars, conferences and other events of the Institute are still a place for engagement with contemporary issues, a centre for public debate and information, and an opportunity for networking. Often the Institute has been prescient in its awareness of important issues. For 
example, in 1961, more than 10 years before the United Kingdom acceded to the European Union, the Institute held a joint meeting in Leiden with the Europa Institute of the University of Leiden - this collaboration continues today - to discuss European community law, with senior British judges and lawyers taking the ferry to attend. The impact and popularity of the Institute's events on contemporary issues owes much to the generous support in funds and people from law firms, barristers' chambers and some companies.

The Institute's research has grown and developed over time, and it has maintained a reputation for its high quality, depth of scholarship, practical application and wide-spread use. A number of its research projects have helped to clarify and define key areas of international and comparative law. These include the law on State immunity; the Convention on the Law of the Sea; the joint development of offshore oil and gas; the law of armed conflict and the 1977 Geneva Protocols; cross-border insolvency; enforcement of judgments; and the various applications of European Union legislation. In addition, the work of the specialist Forums of the Institute, especially on competition law, product liability law and investment treaty law, have supplemented this research and discussion.

Much of this research has been recorded in publications of the Institute, as well as in the International and Comparative Law Quarterly (which was first published in 1952, as a precursor to the merger and successor to the Journal of Comparative Legislation and the Transactions of the Grotius Society) and the Bulletin of International Legal Developments. Until 1998 the Institute's Director was also the General Editor of the Quarterly and the Director is now joint General Editor with, initially, Professor Alan Boyle and then, from 2006, Professor Catherine Redgwell. Many other distinguished academic and practising lawyers and judges have been on the Editorial Board and contributed significantly to the high quality and reputation of the Quarterly.

Over its 50 years, the Institute has been very fortunate in the staff who have ensured that it continues to meet its objectives. Its first Director was Norman Marsh CBE QC, formerly Fellow of University College, Oxford and a Law Commissioner, who was followed by Professor Kenneth Simmonds, who was Director from 1965 to 1982 . During his time, he guided the Institute from a single room in Middle Temple, to a building in Furnival Street, East London to its present location in Russell Square (obtained through the generosity of Charles Clore) and took up the Chair in international law at Queen Mary University of London. In 1982 Lady Hazel Fox CMG QC, formerly Fellow of Somerville College, Oxford, became the Director and when she ended her time as Director in 1992, the ICLQ had a special Editorial in which they praised her "unceasing zeal, dedication and professionalism", which had benefited both the Quarterly and the Institute (47 ICLQ (1998)). Piers Gardner, who had practised as a solicitor, especially on the European Convention on Human Rights, and then as a barrister, was the Director from 1992 to 2000, and he was succeeded by Dr Mads Andenas, an expert in 
European law, who was a barrister in England and Wales, and an advokat in Norway, and they increased the activities of the Institute and introduced some of the specialist Forums. When Mads left in 2005, Stephen Walzer was Acting Director until Professor Gillian Triggs, from the University of Melbourne and practice, commenced her two-year term. In 2008 Professor Robert McCorquodale, from practice and the Universities of Cambridge, Australian National University and Nottingham, commenced as Director.

Yet the Institute is so much more than its Directors. The research and administrative staff are vital to its success, as well as the essential support of its members. The role of the Institute's governing body has been crucial in guiding it, especially during difficult financial times. Indeed, the Institute has been assisted considerably by the financial support from many sources, for which it is very grateful. These sources include endowments from Barnett Shine, Sunley-Percy Rugg and Sunley-Sebag Shaw Foundations, the longterm support from the Dorset Foundation, and the generosity of donors to the various appeals by the Institute, as well as continued funding of specific research projects and events.

Throughout its 50 years the Institute has retained its mission of promoting the rule of law through all its activities. The same core principle, the same commitment to its objectives, and the same determination to provide highquality research, education and informed discussion, will continue to inform the Institute in the years ahead. Indeed, when the Institute was founded, the Editorial in the Quarterly stated that "it is intended that the Institute will become in time the principal British organisation for the encouragement of research and for exchange of views in the whole field of international and comparative law, and that it will be used as a source of objective data by all those concerned-lawyers, government officials, business concerns and others - both in this country and abroad ... [and] make a useful and indeed important contribution to international peace and understanding" (8 ICLQ (1959)). As the Institute celebrates is 50th anniversary, it is hoped that it has achieved the aims of its founders and will continue to do so.

Robert McCorquodale (with thanks to Hazel Fox) 